\title{
Green Activism. The European Parliament's Environmental Committee promoting a European Environmental Policy in the 1970s
}

\author{
Jan-Henrik MEYER
}

\section{Introduction: The European Parliament before direct elections - a deficient parliament?}

The history of the European Parliament (EP), as it is presented in histories of European integration and political science texts, is usually told as a story of "progress" on the route to acquiring the full powers of a representative assembly in a modern democracy. ${ }^{1}$ Not surprisingly, the first direct elections of 1979 are routinely interpreted as the watershed in the history of the EP. ${ }^{2}$ According to this interpretation, the longawaited first vote meant not only the establishment of a direct link to the European citizens and thus greater legitimacy. Researchers also argued that in the wake of direct elections the EP and its members (MEPs) have become more assertive. ${ }^{3}$ This new assertiveness and "activism" (Desmond Dinan) has been attributed to generational change. Most directly elected members were new to the EP and some of them looked down upon their predecessors. A majority of them was committed to European integration. Their ambition was to overcome the restrictions of a solely consultative assembly. ${ }^{4}$ Owing their mandate no longer to their respective national party elites but to the popular vote, MEPs now had an incentive to present themselves as energetic and committed representatives of European citizens' interests and to carve out a more important role for the EP within the European Communities (EC). This new attitude is usually illustrated by the EP's initiative for a "Treaty on European Union" which the assembly eventually accepted with an overwhelming majority in February 1984. Even though this vote remained without immediate consequences, the EP has been

1. Cf. e.g. D. JUDGE, 'Predestined to save the Earth'. The Environment Committee of the European Parliament, in: idem (ed.), A Green Dimension for the European Community. Political Issues and Processes, Frank Cass, London, 1993, pp.186-212, here p.187. For a critique of progressive accounts: M. GILBERT, Narrating the Process. Questioning the Progressive Story of European Integration, in: Journal of Common Market Studies, 46(2008), pp.641-662.

2. E.g. G. BRUNN, Das Europäische Parlament auf dem Weg zur ersten Direktwahl 1979, in: F. KNIPPING, M. SCHÖNWALD (eds.), Aufbruch zum Europa der zweiten Generation: die europäische Einigung 1969-1984, Wissenschaftlicher Verlag Trier, Trier, 2004, pp.47-72, here pp.71 f.

3. D. JUDGE, D. EARNSHAW, The European Parliament (2 ${ }^{\text {nd }}$ edition), Palgrave, Basingstoke, 2008, pp.12-15; G. BRUNN, Die europäische Einigung, Reclam, Stuttgart, 2002, p.212; F. KNIPPING, Rom, 25. März 1957: die Einigung Europas, DTV, München, 2004, pp.214f.

4. D. DINAN, Europe Recast. A History of European Union, Palgrave, Basingstoke, 2004, pp.171, 195;

G. BRUNN, Das Europäische Parlament ..., op.cit., p.71. 
given credit for having shown the way forward towards the subsequent Single European Act (SEA) ${ }^{5}$

The academic literature so far has mainly focused on the role of the EP regarding institutional issues and the development of European parties in the 1970s. ${ }^{6}$ One of the most consequential developments of the 1970s, however, was the broadening of the EC's portfolio of policy-making beyond agriculture and competition. New policies were established, such as social and regional policies. ${ }^{7}$ Relatively little is known about the EP's involvement in actual policy-making. Political scientists occasionally observed growing EP assertiveness in the policy process after direct elections, for instance, in environmental policy. They noted that the EP had increasingly been able to make use of the new procedures from 1979 onwards. ${ }^{8}$ Even though it is usually assumed that EP assertiveness only started with direct elections, this claim, however, is rarely backed up by evidence regarding the role of the EP prior to 1979.

This article challenges the standard assumption that parliamentary assertiveness only emerged after direct elections. Instead, it argues that already in the 1970s the EP was insisting on its role as a representative assembly, for example, by trying to promote and shape the emerging environmental policy. The parliamentary Committee on Public Health and Social Affairs (turned into committee on Public Health and the Environment in 1973) not only expressed its concerns regarding the environment but also devoted much energy to act like a "real" parliament by trying to influence policy, linking the EC to its constituency, and thus contributing to the legitimacy of EC policy-making.

In order to analyse parliamentary assertiveness in a more systematic manner, I will draw on these three core functions of parliaments before presenting the emergence of the new policy field of the environment at the European level. Subsequently I will discuss two case studies based on multi-archival research - namely the First Environmental Action Programme of 1973 as the core document of reference for the new policy and the Directive on the Conservation of Wild Birds of 1979 - the socalled Birds Directive - as a concrete example of policy-making. These cases demonstrate that the EP began to assert its role in (environmental) policy-making alre-

5. See for example: M. GILBERT, Surpassing Realism. The Politics of European Integration since 1945, Rowman \& Littlefield, Lanham, 2003, pp.159 f., 173; D. PREDA, L'action de Spinelli au Parlement européen et le projet d'union européenne (1979-1984), in: W. LOTH (ed.), La gouvernance supranationale dans la construction européenne, Bruylant, Bruxelles, 2005, pp.185-203, here pp.193, 197-199.

6. M.-T. BITSCH, Histoire de la construction européenne de 1945 à nos jours, Ed. complexe, Bruxelles, 2004, pp.214-216; G. BRUNN, Die europäische Einigung, op.cit., p.212; D. DINAN, op.cit., pp. 171 f., 195-198; B. OLIVI, L'Europe difficile: histoire politique de l'intégration européenne, Gallimard, Paris, 2001, pp.266 f.

7. For the incipient research on policy making in the 1970s, see the contributions in: W. KAISER, J.H. MEYER, Non-state actors in European integration in the 1970s: Towards a Polity of Transnational Contestation, in: Comparativ. Special issue, 20(2010), pp.7-104.

8. D. JUDGE, 'Predestined to save the Earth' ..., op.cit., here p.190; D. JUDGE, D. EARNSHAW, The European Parliament, op.cit., pp.34, $42 \mathrm{f}$. 
ady well before direct elections, even though it would require further research to verify whether this claim holds more generally. ${ }^{9}$

\section{What do Parliaments do? Policy influence, linkage and legitimation}

As Berthold Rittberger has demonstrated, parliamentary democracy practiced in member states was the key normative point of reference for the inclusion of a parliamentary assembly into the set of European institutions that were founded in the 1950s. ${ }^{10}$ At the same time, despite the special role of the European Commission and the lip service paid to European federalist ideas, the European Coal and Steel Community (ECSC), the European Economic Community (EEC) and the European Atomic Energy Community (EURATOM), that merged to establish the European Communities (EC) in 1965, had essentially been designed as international organisations for regional economic integration in Western Europe. Only in the course of time, as it encompassed an ever broader range of policies and produced legislation that was binding on the member states, did the EC increasingly resemble an emerging European political system. ${ }^{11}$ As opposed to the situation in standard international organisations, the promise of eventual direct elections to the EP - made already in the Paris Treaty establishing the ECSC - suggested that the EP's role was to conform much more to that of national parliaments.

The comparative study of parliaments has suggested a number of core parliamentary functions that may serve as a benchmark when trying to assess the degree of assertiveness of the EP in the new European environmental policy. Three functions can be distinguished: legitimation, linkage and policy influence. ${ }^{12}$ In democratic political systems, based on the ideal of popular sovereignty, representative assemblies fulfill the function of conferring legitimacy to political decisions. Their assent turns a legislative proposal into binding laws. Taking a constructivist perspective, we are well aware that acts of legitimation rest on convention and a shared "belief" (Legiti-

9. This article draws on the larger project "Protecting the Environment. Transnational Networks in the Emergence of a New EC Policy in the 1970s". This research was supported by a Marie Curie Intra European Fellowship and a Marie Curie Intra European Reintegration Grant within the $7^{\text {th }}$ European Community framework programme, as well as by the Danish Research Council (FKK) within the project "Transnational History", directed by Ann-Christina L. Knudsen, at Aarhus University. It also benefitted from a fellowship at the Kolleg-Forschergruppe (KFG) "The Transformative Power of Europe" www.transformeurope.eu, hosted at Free University Berlin, directed by Tanja Börzel and Thomas Risse, funded by the German Science Foundation (DFG). I am grateful for the comments I received from the participants of the European and International Studies Colloquium at Aarhus.

10. B. RITTBERGER, The Historical Origins of the EU's System of Representation, in: Journal of European Public Policy, 16(2009), pp.43-61.

11. W. KAISER, M. RASMUSSEN, B. LEUCHT (eds.), The History of the European Union. Origins of a Trans- and Supranational Polity 1950-72, Routledge, Abingdon, 2009.

12. D. JUDGE, D. EARNSHAW, The European Parliament, op.cit., pp.12-15. 
mitätsglaube).${ }^{13}$ In the case of the EC, we can observe the process of the construction of the belief that the involvement of the EP in the legislative process was necessary for the legitimacy of European decisions. ${ }^{14}$ While the decisive Isoglucose ruling of $1980,{ }^{15}$ which confirmed the Council's obligation to consult the EP, was surely crucial in reinforcing its legitimacy, the MEPs themselves tried to strengthen their own legitimacy by behaving like an ordinary parliament. Their reports, questions and votes, as well as their rhetoric, can be interpreted as a strategy to construct the EP as a parliament.

Secondly, parliaments provide not only a symbolic, but also a very practical link between policy-makers and "the people". Political parties channel elusive opinions into alternative options. Two modes of linkage can be distinguished. Since they are not able to communicate with all citizens at the same time, politicians make assumptions about the "will of the people" or at least the "will of their voters", drawing on public debates and the media. Viewed through the prism of their own policy preferences, politicians insert these observations into the policy process. The invocation of public opinion or reference to interests affected may be more or less rhetorical. Hence this mode may be called indirect linkage. Members of parliaments are also important interlocutors not only for citizens from their constituencies, but also for public and private interest groups. MEPs have performed such a link to a plurality of national and transnational societal interests for a long time. While this is a more direct mode of linkage, politicians may still be highly selective in whom they choose to listen to and what they insert into the policy process.

Thirdly, parliaments' most important role in practical terms is influencing policymaking. As outlined in the introduction to this special issue, before the SEA the EP lacked the relevant decision-making powers, such as the powers to initiate, to modify or reject. Trying to influence policy-making, the EP was largely limited to parliamentary questions, reports and resolutions. The relevant parliamentary committees used "own initiative" reports and reports on petitions in an attempt to influence the European agenda. ${ }^{16}$ Below, I will try to assess the EP's assertiveness by focusing on how it fulfilled these three functions in an attempt to play its role as a parliament.

13. D. BEETHAM, C. LORD, Legitimacy and the EU, Longman, Essex, 1998, p.3; M. WEBER, Wirtschaft und Gesellschaft: Grundriss der verstehenden Soziologie, Mohr, Tübingen, 1972, pp. 122-124.

14. See e.g. B. RITTBERGER, Building Europe's Parliament, Oxford UP, Oxford, 2007, p.132.

15. E. KIRCHNER, K. WILLIAMS, The Legal, Political and Institutional Implications of the Isoglucose Judgments 1980, in: Journal of Common Market Studies, 22(1983), pp.173-190.

16. Numerous petitions on environmental issues were submitted to the EP in the 1970s. F. PIODI, The Citizen's Appeal to the European Parliament. Petitions 1958-1979, Archive and Documentation Centre (CARDOC), Luxembourg, 2009, pp.19, 41. 


\section{The emergence of environmental policy and its path to the EC}

The construction of the environment as a policy area is a relatively recent phenomenon. While concern for nature protection dates back to the "first green wave" of the turn to the $20^{\text {th }}$ century, ${ }^{17}$ the notion - and in fact also the term "environment" defined in the way we use it today - only appeared on the eve of the 1970s. The idea of the environment was informed by a new understanding of the "blue planet" as a complex ecological system. To prevent toppling its fragile ecological balance, it seemed no longer enough to engage in quick technological fixes in the prevention of pollution, the conservation of nature and the protection of human health. Meeting regularly in the context of international organisations in the course of the 1960s, an emerging "epistemic community"18 of scientific experts developed and established this novel political issue that resonated well with contemporary reports about environmental disasters such as the Torrey Canyon oil spill off the coast of Brittany in 1967. ${ }^{19}$ International organisations such as the Council of Europe and the Organisation for Economic Cooperation and Development (OECD) placed the environment on their agenda at the end of the 1960s. Events in the course of the Council of Europe's "European Conservation Year" and the US "Earth Day" in 1970 publicised and politicised the issue. ${ }^{20}$ Against this backdrop, national governments took the initiative. Modelled on the US National Environmental Policy Act of 1969, the German government introduced an environmental programme in 1971, while France and the UK established environmental ministries. ${ }^{21}$

These national plans for environmental legislation provided the single most important reason for the European Commission's interest in the new policy. As the "guardian of the Treaty", the Commission feared that newly introduced national regulations were to create new non-tariff barriers in the Common Market. Furthermore, European institutions' involvement in international organisations spurred institutional competition about the appropriate forum for making environmental policy. Finally, both Altiero Spinelli, the Commissioner for Industry, and Sicco Mansholt, the Agricultural Commissioner, and short-term Commission President, were deeply

17. C.S.A. van KOPPEN, W.T. MARKHAM, Nature Protection in Western Environmentalism. A Comparative Analysis, in: idem (eds.), Protecting Nature. Organizations and Networks in Europe and the USA, Edward Elgar, London, 2008, pp.263-285, here pp.264-266.

18. P.M. HAAS, Do Regimes Matter? Epistemic Communities and Mediterranean Pollution Control, in: International Organization, 43(1989) pp.377-403.

19. J. MCCORMICK, The Global Environmental Movement (2nd Edition), John Wiley, Chichester, 1995, pp.55-57; K.F. HÜNEMÖRDER, Die Frühgeschichte der globalen Umweltkrise und die Formierung der deutschen Umweltpolitik (1950-1973), Franz Steiner Verlag, Stuttgart, 2004, pp. $146 \mathrm{f} ., 155$.

20. J. MCCORMICK, op.cit., p.78; A. ROME, The Genius of Earth Day, in: Environmental History, 15(2010), pp.194-205.

21. F. UEKÖTTER, Von der Rauchplage zur ökologischen Revolution. Eine Geschichte der Luftverschmutzung in Deutschland und den USA 1880-1970, Klartext, Essen, 2003, p.485; M. BESS, The Light Green Society. Ecology and Technological Modernity in France, 1960-2000, University of Chicago Press, Chicago, 2003, pp.83 f. 
concerned about the consequences of population growth and the increasing use of chemicals in agriculture. Mansholt was member of the Club of Rome, who published its report on the "Limits to Growth" in 1972. This quantitative extrapolation of contemporary trends produced predictions warning against the imminent exhaustion of resources. ${ }^{22}$ In the run-up to the Stockholm UN conference "Man and the Environment" scheduled for the summer of 1972 the Commission encouraged the member states to coordinate their preparations. Mansholt himself presented the Commission's proposals for environmental action in Stockholm. ${ }^{23}$ However, not only the Commission and the Member States were involved in placing the issue of the environment on the EC agenda.

\section{Setting the framework: The First Environmental Action Programme of 1973}

The EP played an important role in the agenda setting 24 that led to the First Environmental Action Programme. Linking to public debates, experts and international organisations, it was the first EC institution to demand Community action. In conjunction with the other European institutions which picked up and subsequently supported these demands, the EP contributed not only to influencing this crucial first step of policy making, but also provided legitimacy for the establishment of a new EC policy.

In the story of the First Environmental Action Programme, the Committee of Public Health and Social Affairs was the first actor to enter the stage. Already before Commissioner Spinelli explained to his colleagues his ideas for environmental action for the first time at the 17/18 February 1971 Commission meeting, ${ }^{25}$ the Committee had launched a first attempt at placing the issue of the environment on the European agenda. Water pollution and the Rhine river, in particular, were the focus of the first "own initiative report" on an environmental issue, produced by the Dutch rap-

22. D. MEADOWS, et al., The Limits to Growth, Universe Books, New York, 1972.

23. E. BUSSIÈRE, Entretien avec Michel Carpentier, Paris, 5 janvier 2004, in: Historical Archives of the European Union, (2004), here pp.15-17; L. SCICHILONE, The Origins of the Common Environmental Policy. The Contributions of Spinelli and Mansholt in the ad hoc Group of the European Commission, in: M. RASMUSSEN, A.-C. LAURING KNUDSEN (eds.), The Road to a United Europe. Interpretations of the Process of European Integration, PIE-Peter Lang, Brussels 2009, pp. 335-348, here pp.362-364. On the reception of the concept of the environment by the EC see: J.-H. MEYER, Appropriating the Environment. How the European Institutions received the Novel Idea of the Environment as a Policy Area and made it their own, in: KFG-Working Paper, Research College "The Transformative Power of Europe", Free University Berlin (forthcoming 2011).

24. On agenda-setting as part of the policy process see: S. PRINCEN, Agenda Setting in the European Union, Palgrave, Basingstoke, 2009; J.-H. MEYER, Getting started: Agenda-setting in European Environmental Policy in the 1970s, in: J. LAURSEN (ed.), From Crisis to New Dynamics: the European Community 1974-83, Bruylant, Brussels, forthcoming 2012.

25. Commission Archive, Brussels, BAC 244/1991 1, European Commission. Proposition pour une action communautaire en matière d'environnement. Communication de M. Spinelli, doc SEC (71) 591, 12.02.1971, pp.1-15 [4-28]. 
porteur Jacob Boersma, a Christian Democratic Labour Unionist. ${ }^{26}$ The Rhine seemed a very suitable object for EC intervention, not least since its floodplain and delta included almost all member states. An environmental disaster in June 1969, the poisoning of the river's fish by the pesticide Thiodan was the factor that prompted the EP to raise the issue. The accident had directed the attention of the "European public sphere" 27 to the situation of the Rhine, as the EP report highlighted, not least because millions of people along the river relied on filtered Rhine water for drinking, agriculture and industry. ${ }^{28}$

Presenting itself as the advocate of citizens' concerns about the natural bases of their livelihood, in this report, as well as in a subsequent one by the German Christian Democrat Hans Edgar Jahn ${ }^{29}$ on air pollution in 1971, 30 the Committee on Public Health and Social Affairs tried to link European policy-making to (international) public debates and concerns. The dominant mode of linkage at this time was an indirect one. Reports refer to the admonitions advanced by international organisations such as the World Health Association (WHO), the OECD, NATO, ${ }^{31}$ the Council of Europe, as well as non-member states' initiatives such as those by Sweden and the USA, and to the UN conference planned for 1972 in Stockholm. ${ }^{32}$ Jahn used media reports - both as a description of the situation and as an indicator of the current public debate - to back up his assessment of the urgency of the issue and his demand for European action. ${ }^{33}$ Both Jahn and Boersma pointed to the expertise and opinions of

26. CARDOC PE0 AP RP/ASOC.1967 0161/70, Europäisches Parlament. Bericht im Namen des Ausschusses für Sozial- und Gesundheitsfragen über die Reinhaltung der Binnengewässer unter besonderer Berücksichtigung der Verunreinigung des Rheins, 11.11.1970, doc 161/70, Berichterstatter: Jacob Boersma (hereafter: Water-Report).

27. For the rhetorical invocation of a "European public sphere" see: J. REQUATE, M. SCHULZEWESSEL, Europäische Öffentlichkeit. Realität und Imagination einer appellativen Instanz, in: idem (eds.), Europäische Öffentlichkeit. Transnationale Kommunikation seit dem 18. Jahrhundert, Campus, Frankfurt, 2002, pp.11-39. See also: J.-H. MEYER, The European Public Sphere. Media and Transnational Communication in European Integration 1969-1991, Franz Steiner, Stuttgart, 2010.

28. Water-Report, here p.10, $\S 28 \mathrm{f}$.

29. On Jahn's biography see: J.-H. MEYER, A good European - Hans Edgar Jahn - Anti-Bolshevist, Cold-Warrior, Environmentalist, in: A.C. LAURING KNUDSEN, K. GRAM-SKJOLDAGER, Living Political Biography. Narrating Ideas of Europe, Aarhus University Press, Aarhus, forthcoming 2011.

30. CARDOC PE0 AP RP ASOC.1967 0181/71, Europäisches Parlament. Bericht im Auftrag des Ausschusses für Sozial- und Gesundheitsfragen über die Notwendigkeit einer Gemeinschaftsaktion zur Reinhaltung der Luft, Berichterstatter Hans Edgar Jahn, 15.12.1971, doc 181/71, (hereafter: AirReport).

31. On the involvement of NATO in environmental policy as advocated by US President Richard Nixon see: J. D. HAMBLIN, Environmentalism for the Atlantic Alliance: NATO's Experiment with the 'Challenges of Modern Society', in: Environmental History, 15(2010), pp.54-75; T. SCHULZ, Transatlantic Environmental Security in the 1970s? NATO's "Third Dimension" as an Early Environmental and Human Security Approach, in: Historical Social Research, 35(2010), pp.309-328.

32. Water-Report, pp.7-10, §12-27, Air-Report, pp.4 f. §40-44.

33. Air-Report, pp.6-11. Jahn quotes from issues of Der Spiegel and Die Zeit published in 1970. 
private and public interest groups, such as the Conseil des Fédérations Industrielles d'Europe (CIFE) of 1966 and the European Consumers' Associations BEUC. ${ }^{34}$

At times, however, reports give evidence of direct linkage: demands for measures on air pollution were informed by the involvement of Committee members in the congress on air pollution in 1966, organised by the German industrial professional organisation of Engineers Verein Deutscher Ingenieure (VDI). ${ }^{35}$ Similarly, members of the Committee - as well as Commissioner Spinelli - participated in an interparliamentary conference on water pollution in Rome in 1971, where they familiarised themselves with the relevant expertise. Jahn accordingly called on the Commission to take up the demands laid down in the conference resolution. ${ }^{36}$ Subsequently, Jahn himself took part in a number of international interparliamentary conferences on the environment, e.g. in Nairobi in 1974 and in Kingston, Jamaica in 1976.37

Parliamentary questions regarding pollution had become more numerous towards the end of the 1960s. While MEPs frequently posed questions relevant to their local constituencies, it remains unclear to what extent MEPs responded to concrete demands by individual citizens or interest groups, thus enabling a direct link to the EC polity. In any case these questions were part of the discursive construction of the environment as a problem for the EC to deal with. Parliamentary questions raised attention to the issue, placed it on the European agenda and required the Commission (and the Council) to respond. More importantly, however, when reiterated in parliamentary reports in great numbers, these questions strengthened the credibility of rapporteurs' demands.

While formally the EP had no decision-making powers and was not directly elected, the Commission treated the EP as well as the Economic and Social Committee (ESC) as legitimate representatives of their constituencies - and a relevant partner within the European institutional game - as the following episode shows. On 31 May 1972, during the discussion of the Commission's Communication on a European Communities' Programme of Action concerning the Environment ${ }^{38}$ in the ESC's

34. Water-Report, p.9, §23; p.11, §30.

35. Air-Report, p.16, §48-51.

36. CARDOC PE0 AP RP ASOC.1967 0009/72, Europäisches Parlament. Bericht im Namen des Ausschusses für Sozial- und Gesundheitsfragen über die Erste Mitteilung der Kommission der Europäischen Gemeinschaften über die Politik der Gemeinschaft auf dem Gebiet des Umweltschutzes, Berichterstatter Hans Edgar Jahn, 14.04.1972, doc 9/72, here p.45, § 55.

37. CARDOC PE0 AP RP/ENVI.1973 0361/74 (1974), European Parliament. Report drawn up on behalf of the Committee on Public Health and the Environment on the Outcome of the Third International Interparliamentary Conference on the Environment held in Nairobi from 8 to 10 April 1974, rapporteur H.E. Jahn, 02.12.1974, doc 361/74; CARDOC PE0 AP RP/ENVI.1976 0012/77, European Parliament. Report drawn up on behalf of the Committee on the Environment, Public Health and Consumer Protection on the Outcome of the Fourth International Interparliamentary Conference on the Environment held in Kingston (Jamaica) from 12 to 14 April 1976, rapporteur H.E. Jahn, 30.03.1977, doc 12/77.

38. European Commission, Communication from the Commission to the Council on a European Communities' Programme concerning the Environment (submitted on 24 March 1972), in: Bulletin of the European Communities, Supplément 5(1972), pp.1-69. 
newly established working group on the environment, the former Commission official and head of the Luxembourg Chamber of Commerce Carlo Hemmer asked the Commission why the problem of the killing of migratory birds had not been included. Hesitant at first, referring to the lack of competences of the EC in this area, DirectorGeneral Robert Toulemon, responsible for the environment in Spinelli's DirectorateGeneral for Industry, explicitly invited protest. If the EP and the ESC demanded so in a statement, he suggested, the Commission would be able to include bird protection in the Programme. ${ }^{39}$ Clearly, Commission officials believed that EP (and ESC) action made Commission initiatives in this new field appear more legitimate. ${ }^{40}$ Besides relying on the legitimacy of the experts from international organizations, Commissioner Haferkamp prominently mentioned the report on the Rhine - as well as the preceding parliamentary questions - in a communication to his fellow Commissioners advocating environmental measures. ${ }^{41}$

\section{Making policy: The Directive on the Conservation of Wild Birds of 1979}

The case of the Birds Directive provides very concrete evidence of pre-1979 parliamentary assertiveness in European environmental policy. More clearly than in the previous case, the EP exerted influence on actual policy-making. It played a major role in placing the issue on the agenda, pressed for binding legislation, attempted to influence its content and tried to push the Council to finally enact the directive. By providing a link for bird and nature protection groups to the EC, the Committee on Public Health and the Environment, and in particular its rapporteur Jahn, not only fulfilled an important parliamentary function, but also strengthened their own influence in policy-making and their own legitimacy as a representative assembly. By picking up what was perceived as a popular concern, the EP arguably contributed to the legitimacy of the new policy. ${ }^{42}$

39. Historical Archives of the European Union, SEC 4298, Florence 1972, Wirtschafts- und Sozialausschuss. Anlage zum Protokoll der 6. Sitzung des Unterausschusses Umwelt am 31.05.1972. Zusammenfassung des Gedankenaustausches zwischen den Vertretern des Unterausschusses und Herrn Toulemon, Vertreter der Kommission, here p.9.

40. See also: N. POHL, Grün ist die Hoffnung - Umweltpolitik und die Erwartungen hinsichtlich einer Reform der Institutionen der Europäischen Gemeinschaft um 1970, in: F.-J. BRÜGGEMEIER, J. I. ENGELS (eds.), Natur- und Umweltschutz nach 1945. Konzepte, Konflikte, Kompetenzen, Campus, Frankfurt 2005. pp. 162-182, here p. 162.

41. Commission Archives, Brussels, BAC 244/1991 1, European Commission. Travaux effectués dans le cadre du rapprochement des législations dans le domaine de la protection de l'environnement, notamment en ce qui concerne le droit des eaux (Lutte contre la pollution des eaux). Communication de M. Haferkamp, doc SEC (71) 602, 12.02.1971, pp.1-14 [30-45], here pp.4-8 [35-39].

42. For a more extensive treatment of this issue see: J.-H. MEYER, Saving Migrants. A Transnational Network supporting Supranational Bird Protection Policy in the 1970s, in: W. KAISER, B. LEUCHT, M. GEHLER (eds.), Transnational Networks in Regional Integration. Governing Europe 1945-83, Palgrave, Basingstoke, 2010, pp.176-198. 
In the early 1970s, parliamentary questions by North European MEPs to the Commission placed the unlikely issue of bird protection on the EC agenda. In the agenda setting phase, indirect linkage dominated. However, MEP Lord Chelwood was directly linked to a non-governmental organisation. When posing a question, he emphasised that he was raising the issue as a former president of the Royal Society for the Protection of Birds (RSPB). ${ }^{43}$ MEPs referred to recent media reports about the large-scale trapping and hunting of small migrant birds in Southern EC member states and suggested to the Commission to propose measures to stop this killing. Using ecological and economic arguments, they pointed to the useful role that songbirds played by eating harmful insects - a role that would otherwise have to be replaced by poisonous pesticides. ${ }^{44}$ When justifying the inclusion of the issue in the Environmental Action Programme, the Commission quoted the same arguments as the EP, namely, parallel joint action in the framework of the Strasbourg-based Council of Europe and a study concerning the possible harmonisation of bird protection legislation. Parliamentary questions may not have been the sole source of such arguments. Indeed, the Commission had received press reports and citizens' letters on this issue, too. These different sources of societal input amplified each other and provided a sounding board for EP questions. Thus the issue started resonating with the Commission, which was formally in charge of proposing policy, and was subsequently placed on the European agenda. ${ }^{45}$

Grasping the opportunity provided by the petition "Save the Migratory Birds", submitted by the Dutch Stichting Mondiaal Alternatief, the Committee on Public Health and the Environment appointed Jahn to write a report on bird protection in 1974. Jahn, who was personally very involved in this issue, was not satisfied with limiting EC action to the Council recommendation that was adopted at the end of 1974. In order to stop the hunting of small birds, he demanded binding legislation. ${ }^{46} \mathrm{Jahn}$ directly linked up with bird and animal protection groups and activists. His letters show that from early 1975 onwards he became part of a transnational network of communication among groups and individuals that coordinated the protest in fa-

43. Lord Tufton Victor Chelwood, Oral question (doc 12/74) 'Protection of Wild Birds especially Migratory Birds' and explanatory statement, 15.05.1974, in: Official Journal of the European Communities (hereafter: OJEC), Annex: Proceedings of the European Parliament (1974), p.104.

44. E.g. Jean-Pierre Glesener, Written Question $n^{\circ} 285 / 71,10.09 .1971$, to the Commission concerning killing of migratory birds in Belgium and Italy, in: OJEC, 14 C119, 26.11.1971; Horst Seefeld, Question écrite ${ }^{\circ} 253 / 72,08.08 .1972$, à la Commission des Communautés européennes, in: ibid., 15 C120, 17.11.1972.

45. Commission of the European Communities, Programme of Environmental Action of the European Communities. Part II: Detailed description of the actions to be undertaken at Community level over the next two years. Forwarded by the Commission to the Council, COM (73) 530 final C, 10 April 1973, here p.II.67f. Available on: http://aei.pitt.edu/5451/01/001084_1.pdf [last accessed: 07.11.2010].

46. Archive of the Council of Ministers, Liste Rouge 2680, Hans Edgar Jahn, Report drawn up on behalf of the Committee on Public Health and the Environment on Petition n ${ }^{\circ} 8 / 74$ "Save the Migratory Birds", doc. 449/74, PE 38.979fin, 07.02.1975. 
vour of European bird protection. ${ }^{47}$ Jahn even had information produced by the bird protection groups distributed directly to the members of the committee. ${ }^{48}$ In the parliamentary debate on the issue in February 1975, Commissioner Guido Brunner conceded that the Commission would propose a directive, if the Council recommendation did not produce "satisfactory results". ${ }^{49}$ However, it took further parliamentary questions prepared by Jahn and debated in the $\mathrm{EP}^{50}$ before the Commission actually submitted its proposal for a directive in December $1976 .{ }^{51}$ In the meantime the Commission had gathered the relevant scientific evidence to make a credible case not only for measures to limit hunting but also to protect habitats. Jahn produced a parliamentary report on the proposal, and a draft resolution calling for amendments such as compulsory consultation of the EP when exemptions to bans on hunting were granted. ${ }^{52}$ In this context, the European hunting organisations were eventually consulted by rapporteur Jahn, too. They had pressed for a meeting, since they felt inadequately represented. This does not only provide evidence for the EP's fulfilling the function of linkage, and the problems of equal representation. It also demonstrates that societal actors clearly recognised the EP as an influential player within the EC. ${ }^{53}$ The Commission took up some of the EP's suggestions - notably the shortening of the transition period for the transposition of the directive - in a revised proposal of July $1977 .{ }^{54}$ Fixing shorter deadlines clearly improved the bargaining position of the Commission in the subsequent Council negotiations. Further parliamentary questions, ${ }^{55}$ in conjunction with transnational campaigns by animal and bird protection

47. Archiv für Christlich-Demokratische Politik, Konrad Adenauer Stiftung (hereafter: ACDP), Nachlaß Hans-Edgar Jahn, Umweltschutz Tierschutz Schriftwechsel 098/2.

48. CARDOC PE0 AP RP ENVI.1973 A0-0449/74, Committee on Public Health and the Environment European Parliament, Notice to Members: Report by Mr Uberti, Secretary of the Verona Branch of the National Society for the Protection of Animals, on the Trade in Birds in the Mediterranean Region, particularly in Italy, 30 October 1974.

49. European Parliament. Debate on Petition $n^{\circ} 8 / 74$ "Save the Migratory Birds", 21.02.1975, in: OJEC, Annex: Proceedings of the European Parliament, pp.262-267, here p.266.

50. European Parliament. Oral Question with Debate (O-58/75, doc 473/75): Bird Protection, Session 09.02.1976, in: OJEC, Annex: Proceedings of the European Parliament, pp.8-15; European Parliament, Oral Question with Debate (O-58/76, doc 329/76): Protection of Birds, Session 15.10.1976, in: OJEC, Annex: Proceedings of the European Parliament, pp.265-270.

51. Council Archive, Liste Rouge 2772, European Commission. Proposal for a Council directive on Bird Conservation, 20.12.1976, COM (76) 676 final.

52. European Parliament, Resolution of the European Parliament on the Proposal of the Commission of the European Communities to the Council concerning a Directive on Bird Conservation, 14.06.1977, in: OJEC, 21(1977), pp.28-32.

53. ACDP, Nachlaß Hans-Edgar Jahn, 098/5, Berthold Küster, Notizen über die informelle Gesprächsrunde mit Vertretern europäischer Jagd- und Vogelschutzverbände am Donnerstag, 13.05.1977.

54. Archive of the Economic and Social Committee, Brussels. Dossier: Proposition de Directive du Conseil concernant la conservation des oiseaux doc (76) 676 final [340.145:591.615] 636.6, European Commission. Modification of the proposal for a Directive of the Council concerning the Conservation of Birds, doc COM (77) 379 final, 29.07.1977.

55. CARDOC PE0 AP QP!QO O-34/78, Hans Edgar Jahn, Oral question (O-34/78) with debate by Mr Jahn on behalf of the Christian Democratic Group to the Commission. Subject: Imminent Prospect of the Commission's Proposal for a Directive on Bird Protection not being adopted, doc 195/78 rev. PE 54116, 26.06.1978. 
groups lobbying national governments and the European institutions, and eventually the involvement of national governments trying to convince the recalcitrant French government led to the final acceptance of the Birds Directive in December 1978. ${ }^{56}$

Parliamentary support - directly linked to demands from what is now called European civil society and from the European public sphere of the media - contributed to legitimising the project vis-à-vis the recalcitrant Council. While this effect was mostly limited to relations among the European institutions and governments of member states, MEPs certainly also hoped to gain legitimacy vis-à-vis their future voters by associating themselves with this popular cause, just as Commission officials hoped that its popularity would rub off on the EC itself. ${ }^{57}$

The Birds Directive was originally motivated by Northern European resentment against the hunting of songbirds in Southern Europe, a resentment clearly shared but also deliberately utilised to stress the urgency of the issue - by Jahn and many of his colleagues. Not least due to EP pressure, the Directive introduced remarkably strict rules on habitats protection valid in all member states. It provided an important precedent for EC action in the area of nature protection and paved the way for the Habitats directive of 1992 and the Natura 2000 Programme. ${ }^{58}$

\section{Conclusions}

Three conclusions can be drawn from the two cases of EP involvement in early environmental policy. First, these examples of EP assertiveness suggest that the Committee's commitment "to save the earth" has a long history that goes back to the start of EC environmental policy. ${ }^{59}$ It predates direct elections. The EP - represented by its relevant Committee - was the first Community institution trying to place environmental policy on the EC agenda. Regarding the Birds Directive the EP played an important role throughout the entire policy cycle. Even if formally powerless, the EP was able to influence policy-making under the specific conditions of the emerging policy. With the content of the policy not yet clearly defined, the Commission was open to parliamentary initiatives in exchange for the legitimacy provided by EP sup-

56. For more detailed information on the involvement of environmental groups: J.-H. MEYER, Greening Europe? Environmental Interest Groups and the Europeanization of a New Policy Field, in: Comparativ, 20(2010), pp.83-104, here pp.92-102.

57. E.g. Interview with Claus Stuffmann, former Head of Unit in the European Commission's Service for the Environment and Consumer Protection, Brussels 10 June, 2009.

58. W.P.J. WILS, The Birds Directive 15 Years Later. A Survey of the Case Law and Comparison with the Habitats Directive, in: Journal of Environmental Law, 6(1994), pp.219-242.

59. D. JUDGE, 'Predestined to save the Earth' ..., op.cit.; C. KNILL, T. BERNHEIM, Das Europäische Parlament zwischen Umweltschutz und Wettbewerbsfähigkeit. Entscheidungsfindung und Konfliktlinien am Beispiel der Revision der Richtlinie zum Emissionshandel, in: Zeitschrift für Umweltpolitik und Umweltrecht, 33(2010), pp.165-192, here pp.165 f. 
port. As opposed to what is often claimed in the literature, such an exchange took place already before direct elections. ${ }^{60}$

Secondly, while this article focuses on the EP as a single supranational institution, its role can only be adequately understood by situating it in its cooperative context. Given its lack of formal powers, the EP relied on cooperative exchange relations also with non-state actors. By providing linkage, the EP not simply fulfilled its democratic function, but also strengthened its own role. The Committee borrowed arguments and expertise, indirectly or directly linking up to international organisations, European publics and interest groups, to advance its own cause. By directly cooperating with a transnational network of NGOs and experts, rapporteur Jahn was able to transnationally link his actions to protest movements across European societies. This coordinated protest opened an additional, indirect route for lobbying the national governments who had the final say in the Council. Whether and to what extent the MEPs granted disproportionate access to a vocal, well-organised minority of radical bird lovers, is a normative question that deserves further research.

Thirdly, the case studies suggest that 1979 was less of a turning point than usually assumed. The anticipation of direct elections may have played a certain role as a motivation for parliamentary assertiveness. For instance, Jahn's engagement in favour of bird protection was intensified by electoral concerns. He held a public meeting with representatives of European bird protection groups in his home constituency in Braunschweig in March 1978 and took great care to sell his defence of the songbirds to the local and national press in the run-up to the elections. ${ }^{61}$ Nonetheless, my findings challenge the view that direct elections provided the decisive boost in legitimacy that explains an apparently new assertiveness. Already before direct elections, there is ample evidence of MEPs' active engagement in environmental policy. MEPs tried to advance and influence policy and hold the Council to account - when they suspected dilatory action. Their skilful use of the few instruments available to them - parliamentary questions, own initiative reports as well as cooperating with nongovernmental groups - suggests that they had little doubt about the legitimacy of their actions as members of a supranational parliament representing the Europeans. Against this backdrop, it would be worth inquiring further into MEPs' perceptions of their own role in supranational policy-making before and after direct elections beyond simple generalisations about their federalist zeal and institutional self-assertion. ${ }^{62}$

60. D. JUDGE, D. EARNSHAW, The European Parliament, op.cit., p.39.

61. ACDP, Nachlaß Hans-Edgar Jahn, Presse 093/1: Artikel von und über Hans Edgar Jahn. E.g. Experten für den Vogelschutz, in: Braunschweiger Zeitung, 15.03.1978, Vogelschutz europaweit, in: Handelsblatt, 27.03.1978.

62. Such issues are currently studied by Ann-Christina Lauring Knudsen and collaborators in the research project "Transnational History" in Aarhus, see: http://iho.au.dk/en/department/other-activities/transnationalhistory/. 


\section{European Integration in the Discourse}

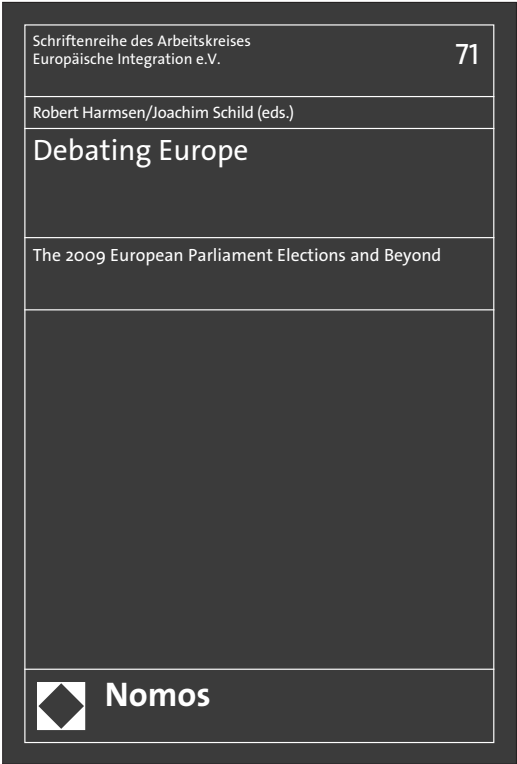

\section{Debating Europe}

The 2009 European Parliament Elections and Beyond

Edited by Prof. Dr. Robert Harmsen

and Prof. Dr. Joachim Schild

2011, 280 pp., pb., € 49.00

ISBN 978-3-8329-5807-7

(Schriftenreihe des Arbeitskreises

Europäische Integration e.V., vol. 71)

nomos-shop.de/12757
The book offers a selection of thirteen country studies on the European Parliament election campaigns and the recent developments of national debates surrounding European integration, further allowing for a comparative reflection on the more general evolution and limits of discourses concerning the European integration project. Comparisons are drawn across four principal axes of discourses: the political project of European integration, the social and economic project of European integration, the preservation of national identity, and the differences in prevailing national 'prointegrationist' discourses.

This thematic cataloguing facilitates a 'mapping' exercise-looking for distinctive patterns of the framing of European issues which are shared by definable subsets of member states. The editors identify overall trends across countries such as the toning down of federalist discourses in the founding member states. 